\title{
Assimilation of metals in marine copepods and its biogeochemical implications*
}

\author{
Nicholas S. Fisher ${ }^{1}$, Canice V. Nolan ${ }^{2}$, Scott W. Fowler ${ }^{2}$ \\ ${ }^{1}$ Marine Sciences Research Center, State University of New York, Stony Brook, New York 11794-5000, USA \\ ${ }^{2}$ I.A.E.A. International Laboratory of Marine Radioactivity, 19 Av. des Castellans, MC-98000 Monaco
}

\begin{abstract}
Laboratory experiments employing gamma-emitting radiotracers assessed the retention efficiency of ingested metals in the calanoid copepod Anomalocera patersoni and the retention of excreted metals in fecal pellets. Adult copepods ingested the haptophyte Isochrysis galbana labeled with ${ }^{109} \mathrm{Cd}^{65} \mathrm{Zn},{ }^{203} \mathrm{Hg},{ }^{241} \mathrm{Am}$ and ${ }^{237} \mathrm{Pu}$ at a rate of $3.79 \mathrm{mg}$ algal $\mathrm{C} \mathrm{g}^{-1}$ animal dry wt $\mathrm{h}^{-1}$. Average retention efficiencies were $30 \%$ for $\mathrm{Cd}, 48 \%$ for $\mathrm{Zn}, 21 \%$ for $\mathrm{Hg}, 4.5 \%$ for $\mathrm{Am}$, and $0.8 \%$ for Pu. Algal cells resuspended into unlabeled seawater retained metals to varying extents, with depuration curves conforming to a 2-compartment model; $\mathrm{Cd}$ was lost most rapidly. The fecal pellets produced by animals feeding on radioactive $I$. galbana lost essentially all of their ${ }^{109} \mathrm{Cd},{ }^{65} \mathrm{Zn},{ }^{241} \mathrm{Am}$, and ${ }^{237} \mathrm{Pu}$ to unlabeled seawater within $1 \mathrm{~d} .{ }^{203} \mathrm{Hg}$ was lost most slowly, again conforming to a 2-compartment model; its retention half time was about $25 \mathrm{~d}$ in the slowly exchanging pool. Bacterial activity did not appear to have an effect on metal retention in the fecal peliets. The retention efficiencies suggest that $\mathrm{Cd}, \mathrm{Zn}$, and $\mathrm{Hg}$ should be recycled by copepods in surface waters as part of the organic cycle in the sea, while the transuranic elements should be defecated and removed from surface waters by sinking biogenic debris.
\end{abstract}

\section{INTRODUCTION}

Cycling of elements in marine systems can be strongly influenced by the resident biota. In surface pelagic waters, plankton can strongly affect vertical transport of elements (Fowler 1982, Fowler \& Knauer 1986). Biogenic particle flux can account for much of the vertical flux and hence control the residence times of particle-reactive elements in the sea (Cherry et al. 1978, Santschi 1984, Wangersky 1986, Fisher et al. 1988, Moore \& Dymond 1988, Murray et al. 1989). Marine zooplankton play a major role in determining the fate of metals, especially particle-reactive metals in the water column (Fowler \& Knauer 1986, Fisher \& Fowler 1987). By 'packaging' some elements into rapidly sinking fecal pellets, crustacean zooplankton such as euphausiids and copepods can effectively remove metals from surface waters (Fowler 1977. Fisher et al. 1983b. Fisher \& Fowler 1987). Those metals which, when ingested in food, show little assimilation in these organisms and are mostly defecated have relatively short residence times in surface waters, while

\footnotetext{
- Contribution no. 773 from the Marine Sciences Research Center
}

metals which are assimilated enter the organic cycle in the sea, are recycled in surface waters, and have longer residence times in surface waters (Whitfield \& Turner 1987).

To better understand the geochemical cycling of metals in marine waters, therefore, it is important to study the fate of ingested elements in those species which are important components of the zooplankton community, since models have shown that the zooplankton in particular are most responsible for the flux of particle-reactive elements from the mixed layer (Bruland \& Coale 1986, Fisher \& Fowler 1987). Specifically, it is important to quantify the retention of ingested metals in zooplankton and the retention times of egested metals associated with fecal pellets. The latter information would enable a more realistic appraisal of the extent to which defecated metals would be transported to deep waters by sinking fecal pellets. Toward this end, we have conducted experiments to examine the fate of ingested metals in a marine copepod which is abundant in the surface waters of the Mediterranean Sea. Despite their importance in zooplankton communities, copepods have been relatively little studied with regard to their retention and excretion of ingested metals. 


\section{MATERIALS AND METHODS}

Copepods were collected in August 1989 from surface waters $5 \mathrm{~km}$ off Monaco using a 333 um nylon mesh net, sorted by sequential seiving, and held overnight in filtered aerated seawater to empty their guts. Microscopic examination of the large fraction indicated that virtually all specimens were adult Anomalocera patersoni, a calanoid copepod.

The experimental copepods were fed radiolabeled Isochrysis galbana cells which had been prepared as follows. Log-phase cells, cultured in Mediterranean surface seawater enriched with $\mathrm{f} / 2$ nutrients (Guillard \& Ryther 1962) minus $\mathrm{Cu}, \mathrm{Zn}$, and EDTA, and which had been sterile-filtered through $0.2 \mu \mathrm{m}$ Nuclepore polycarbonate membranes, were collected out of their growth medium by centrifugation $(9220 \times \mathrm{g}, 10 \mathrm{~min})$. Cells were then resuspended into 2 flasks, each containing $100 \mathrm{ml}$ fresh sterile-filtered surface water, to give a cell density of ca $1.4 \times 10^{6} \mathrm{ml}^{-1}$. One flask received $214.6 \mathrm{kBq}{ }^{109} \mathrm{Cd}\left(\mathrm{t}_{1 / 2}=462 \mathrm{~d}\right), 65.5 \mathrm{kBq}{ }^{65} \mathrm{Zn}\left(\mathrm{t}_{1 / 2}\right.$ $=244 \mathrm{~d})$, and $3.7 \mathrm{kBq}{ }^{203} \mathrm{Hg}\left(\mathrm{t}_{1 / 2}=47 \mathrm{~d}\right)$, all of which were dissolved in $0.1 \mathrm{~N} \mathrm{HCl}$ (total volume added: 44 $\mu l)$. These radionuclide additions corresponded to additions of $6 \mathrm{ng}$ total (including stable) $\mathrm{Cd}, 30 \mathrm{ng}$ total $\mathrm{Zn}$, and $1.1 \mu \mathrm{g}$ total $\mathrm{Hg}$ and yielded final concentrations in the flasks of $0.5 \mathrm{nM} \mathrm{Cd}, 4.6 \mathrm{nM} \mathrm{Zn}$, and $55 \mathrm{nM} \mathrm{Hg}$. The other flask received $37.0 \mathrm{kBq}{ }^{241} \mathrm{Am}\left(\mathrm{t}_{1 / 2}=433 \mathrm{yr}\right)$ plus $25.9 \mathrm{kBq}^{237} \mathrm{Pu}\left(\mathrm{t}_{1 / 2}=45 \mathrm{~d}\right)$, both in solutions dissolved in $3 \mathrm{~N} \mathrm{HNO}_{3}$. The ${ }^{237} \mathrm{Pu}$ was adjusted to the (VI) oxidation state (Lovett \& Nelson 1981) prior to its addition to the algal culture. These additions resulted in final concentrations of $12 \mathrm{nM}$ for ${ }^{241} \mathrm{Am}$ and $21.5 \mathrm{pM}$ for ${ }^{237} \mathrm{Pu}$. The $\mathrm{pH}$ of the flask was adjusted with $\mathrm{NaOH}$ prior to the addition of the isotope so that after isotope addition (total volume $1.005 \mathrm{ml}$ ) pH was 8.0. Radionuclides were purchased from Amersham $\left({ }^{109} \mathrm{Cd},{ }^{65} \mathrm{Zn},{ }^{203} \mathrm{Hg},{ }^{241} \mathrm{Am}\right)$ and from U.K.A.E.A. Harwell $\left({ }^{237} \mathrm{Pu}\right)$.

The cultures were maintained in the dark at $22^{\circ} \mathrm{C}$ for $6 \mathrm{~d}(\mathrm{Cd} / \mathrm{Zn} / \mathrm{Hg}$ exposure) or $4 \mathrm{~d}(\mathrm{Am} / \mathrm{Pu}$ exposure). Following the uptake period, a $5 \mathrm{ml}$ aliquot from each culture was taken to determine by gamma counting the quantity of isotope associated with cells (Fisher et al. 1983a), and a $1 \mathrm{ml}$ aliquot was removed for cell counting. From knowledge of cell counts, it was calculated that each cell exposed to the transuranic elements contained $135 \mu \mathrm{Bq}{ }^{241} \mathrm{Am}$ and $201 \mu \mathrm{Bq}{ }^{237} \mathrm{Pu}$, and each of the other cells contained $555 \mu \mathrm{Bq}{ }^{109} \mathrm{Cd}, 309 \mu \mathrm{Bq}{ }^{65} \mathrm{Zn}$, and $9.9 \mu \mathrm{Bq}$ ${ }^{203} \mathrm{Hg}$. Cells were centrifuged and resuspended into unlabeled seawater so that $\mathrm{Am} / \mathrm{Pu}$-labeled cells and $\mathrm{Cd} / \mathrm{Zn} / \mathrm{Hg}$-labeled cells were pooled; $53.29 \%$ of the pooled cells had been labeled with $\mathrm{Am} / \mathrm{Pu}$ and $46.71 \%$ labeled with $\mathrm{Cd} / \mathrm{Zn} / \mathrm{Hg}$. Thus, the average cell contained $259 \mu \mathrm{Bq}$ of ${ }^{109} \mathrm{Cd}, 144 \mu \mathrm{Bq}$ of ${ }^{65} \mathrm{Zn}, 4.6 \mu \mathrm{Bq}$ of ${ }^{203} \mathrm{Hq}, 72 \mu \mathrm{Bq}$ of ${ }^{241} \mathrm{Am}$, and $107 \mu \mathrm{Bq}$ of ${ }^{237} \mathrm{Pu}$.
Four erlenmeyer flasks, each containing $400 \mathrm{ml}$ of seawater with $1.14 \times 10^{5}$ stationary phase cells $\mathrm{ml}^{-1}$. were prepared. Isochrysis galbana cell density in these feeding suspensions corresponded to $6.5 \times 10^{9} \mathrm{um}^{3} \mathrm{l}^{-1}$, or $1.25 \mathrm{mg} \mathrm{Cl}^{-1}$ (Pechenik \& Fisher 1979), a level which supports maximal ingestion rates in other calanoid copepods (Kiørboe et al. 1985). To each flask 200 copepods were added, and the flasks were incubated in the dark for $18 \mathrm{~h}$ at $16^{\circ} \mathrm{C}$. A fifth flask containing $4 \times 10^{4} \mathrm{I}$. galbana cells $\mathrm{ml}^{-1}$ and no copepods was incubated for $8 \mathrm{~d}$ under the same experimental conditions to determine the rate of release of the metals from the cells.

After feeding, cells were counted microscopically with a hemacytometer to determine the quantity of cells ingested. The fractionation of isotope between dissolved and particulate phases was also determined at this time (Fisher et al. 1983a). Additionally, the copepods were collected on a $333 \mu \mathrm{m}$ mesh, placed in a plastic counting vial containing unlabeled seawater, and their radioactivity quickly determined. The copepods were then resuspended into unlabeled seawater and fed unlabeled Isochrysis galbana cells for $6 \mathrm{~h}$ to purge their guts of any remaining undigested labeled food. These copepods were then recounted to determine residual radioactivity in their tissues. Retention efficiency (RE) of ingested metal was determined by dividing the radioactivity of the copepods after gut evacuation $(\mathrm{BqR})$ by the radioactivity ingested $(\mathrm{BqI}=$ number of cells eaten $(\mathrm{CI}) \times$ radioactivity cell $\left.{ }^{-1}\right)$; this is essentially comparable to the assimilation coefficient or utilization efficiency referred to in radioecological literature (e.g. Lowman et al. 1971).

Fecal pellets produced by the copepods during the $18 \mathrm{~h}$ feeding period were collected from each of the flasks, pooled, and divided into 2 sealed plastic counting vials each containing $5 \mathrm{ml}$ of sterile-filtered seawater. After determining the radioactivity of each group of fecal pellets, the volume of seawater in each vial was increased to $50 \mathrm{ml}$. One of the vials was then incubated at $15^{\circ} \mathrm{C}$ and the other at $2{ }^{\circ} \mathrm{C}$. The fecal pellets remained at the bottom of the vials, which were left stationary. Periodically, $45 \mathrm{ml}$ of water was gently pipetted off the top from each vial and its radioactivity counted, reflecting the release of isotope from the fecal pellets. Radioactivity associated with the undisturbed fecal pellets was also determined before the addition of a fresh batch of $45 \mathrm{ml}$ unlabeled filtered seawater and further incubation.

Radioactivity was determined in a high-purity Ge detector linked to a Cosynus multichannel analyzer and a computer with spectra-analysis software (Intertechnique, Grenoble). The detector was calibrated for energy and counting efficiency with appropriate standards for each of the geometries used. Photon emis- 
sions of ${ }^{109} \mathrm{Cd}$ were determined at $88 \mathrm{keV},{ }^{65} \mathrm{Zn}$ at 1115 $\mathrm{keV},{ }^{203} \mathrm{Hg}$ at $279 \mathrm{keV}$, and ${ }^{237} \mathrm{Pu}$ at $97,101,114$ and 117 $\mathrm{keV}$. The emissions of ${ }^{241} \mathrm{Am}$ at $60 \mathrm{keV}$ were corrected for the minor contribution of a ${ }^{237} \mathrm{Pu}$ peak at this energy. Counting times varied from 2 to $60 \mathrm{~min}$ and propagated counting errors were generally less than $5 \%$ at the 10 level. However, as the depuration experiments continued, decreased radioactivity in some of the samples resulted in counting errors up to $30 \%$.

\section{RESULTS}

Copepods in the 4 flasks ingested variable amounts of algal cells during the $18 \mathrm{~h}$ feeding period (Table 1 ), with an average of ca $9.3 \times 10^{4}$ cells eaten ind ${ }^{-1}$. This corresponds to an average copepod ingestion rate of $3.79 \mathrm{mg}$ algal $\mathrm{C} \mathrm{g}^{-1}$ animal dry $\mathrm{wt} \mathrm{h}^{-1}$, or ca one third of their dry wt $\mathrm{d}^{-1}$. An average of $42 \pm 14 \%$ of the total cells present in the flasks was consumed. Radioactivity ingested per copepod was calculated by multiplying the numbers of cells ingested by the mean radioactivity per cell during the feeding period, taking into consideration loss of radioactivity of each of the radionuclides from the algal cells in the feeding suspensions (see below). Although copepods ingested particulate ${ }^{109} \mathrm{Cd}$ $>{ }^{65} \mathrm{Zn}>{ }^{237} \mathrm{Pu}>{ }^{241} \mathrm{Am}>{ }^{203} \mathrm{Hg}$ (i.e. Bq radioactivity copepod ${ }^{-1}$, simply reflecting the activity of each radionuclide in the algae), they retained ${ }^{65} \mathrm{Zn}>{ }^{109} \mathrm{Cd}>$ ${ }^{241} \mathrm{Am}>{ }^{203} \mathrm{Hg} \geq{ }^{237} \mathrm{Pu}$ (Table 1). Most significantly, metal retention efficiencies $\left({ }^{65} \mathrm{Zn}>{ }^{109} \mathrm{Cd}>{ }^{203} \mathrm{Hg}>\right.$
${ }^{241} \mathrm{Am}>{ }^{237} \mathrm{Pu}$ ) in the copepods ranged from 0.8 $\pm 0.2 \%$ for ${ }^{237} \mathrm{Pu}$ to $48 \pm 17 \%$ for ${ }^{65} \mathrm{Zn}$ (Table 1 ). Retention efficiencies for the transuranic elements were about 1 order of magnitude lower than those for the other metals. Because copepod body burdens of ${ }^{241} \mathrm{Am}$ and ${ }^{237} \mathrm{Pu}$ were so low $(0.189$ and $0.06 \mathrm{~Bq}$ copepod $^{-1}$, indicating 4.5 and $0.8 \%$ retention respectively; Table 1) after gut evacuation, it is unlikely that dissolved ${ }^{109} \mathrm{Cd},{ }^{65} \mathrm{Zn}$, or ${ }^{203} \mathrm{Hg}$ released by the algae or feces in the feeding suspension contributed substantially to body burden in the copepods. In fact, these particle-reactive transuranic elements have partition coefficients for abiotic and biological particulate matter in seawater that are 1 to 2 orders of magnitude higher than those of the transition metals studied here (Fisher 1986, Clegg \& Sarmiento 1989), suggesting that the only significant source of the ${ }^{109} \mathrm{Cd},{ }^{65} \mathrm{Zn}$, and ${ }^{203} \mathrm{Hg}$ for the copepods was ingested food.

The Isochrysis galbana cells lost varying amounts of their radionuclide contents during the $18 \mathrm{~h}$ feeding period. Cadmium displayed the lowest retention, with an average of $25 \pm 7 \%$ of ${ }^{109} \mathrm{Cd}$ retained by cells in the 4 flasks, while ${ }^{237} \mathrm{Pu}$ displayed the greatest retention, with an average of $64 \pm 7 \%$ retained (Fig. 1). I. galbana cells in the absence of copepods displayed a rapid loss of metal within the first $18 \mathrm{~h}$, after which the activity per cell remained essentially constant (Fig. 2). Given that the metals partition between 'dissolved' and particulate phases in accordance with an equilibrium, most of this rapid metal loss within the first $18 \mathrm{~h}$ was probably attributable to the lowering of the suspended

Table 1. Anomalocera patersoni. Algal cells ingested (CI), radioactivity ingested (BqI), radioactivity retained (BqR), and retention efficiency (RE) for 5 metals in the copepod. Values are for individual copepods in each of 4 flasks. Means and standard deviations (SD) also shown

\begin{tabular}{|c|c|c|c|c|c|c|c|}
\hline & \multirow[t]{2}{*}{ Metal } & \multicolumn{4}{|c|}{ Flask } & \multirow[t]{2}{*}{ Mean } & \multirow[t]{2}{*}{$\mathrm{SD}$} \\
\hline & & 1 & 2 & 3 & 4 & & \\
\hline $\mathrm{CI}\left(\times 10^{4}\right)$ & & 11.95 & 7.3 & 5.02 & 12.75 & 9.255 & 3.211 \\
\hline \multirow[t]{5}{*}{$\mathrm{BqI}$} & $\mathrm{Cd}$ & 19.517 & 11.923 & 8.492 & 20.822 & 15.189 & 5.147 \\
\hline & $\mathrm{Zn}$ & 13.806 & 8.428 & 6.004 & 14.720 & 10.740 & 3.641 \\
\hline & $\mathrm{Hg}$ & 0.405 & 0.247 & 0.175 & 0.431 & 0.315 & 0.107 \\
\hline & Am & 6.274 & 3.833 & 2.730 & 6.694 & 4.883 & 1.655 \\
\hline & $\mathrm{Pu}$ & 10.496 & 6.412 & 4.567 & 11.197 & 8.168 & 2.768 \\
\hline \multirow[t]{5}{*}{$\mathrm{BqR}$} & $\mathrm{Cd}$ & 2.880 & 4.465 & 3.550 & 5.090 & 3.996 & 0.846 \\
\hline & $\mathrm{Zn}$ & 4.320 & 4.695 & 4.320 & 5.080 & 4.604 & 0.315 \\
\hline & $\mathrm{Hg}$ & 0.051 & 0.098 & 0.021 & 0.084 & 0.063 & 0.030 \\
\hline & $\mathrm{Am}$ & 0.161 & 0.136 & 0.221 & 0.238 & 0.189 & 0.042 \\
\hline & $\mathrm{Pu}$ & 0.069 & 0.052 & 0.053 & 0.066 & 0.060 & 0.008 \\
\hline \multirow[t]{5}{*}{$\operatorname{RE}(\%)$} & $\mathrm{Cd}$ & 14.8 & 37.4 & 41.8 & 24.4 & 29.6 & 10.7 \\
\hline & $\mathrm{Zn}$ & 31.3 & 55.7 & 72.0 & 34.5 & 48.4 & 16.6 \\
\hline & $\mathrm{Hg}$ & 12.6 & 39.7 & 12.0 & 19.5 & 21.0 & 11.2 \\
\hline & Am & 2.6 & 3.5 & 8.1 & 3.6 & 4.5 & 2.1 \\
\hline & $\mathrm{Pu}$ & 0.7 & 0.8 & 1.2 & 0.6 & 0.8 & 0.2 \\
\hline
\end{tabular}




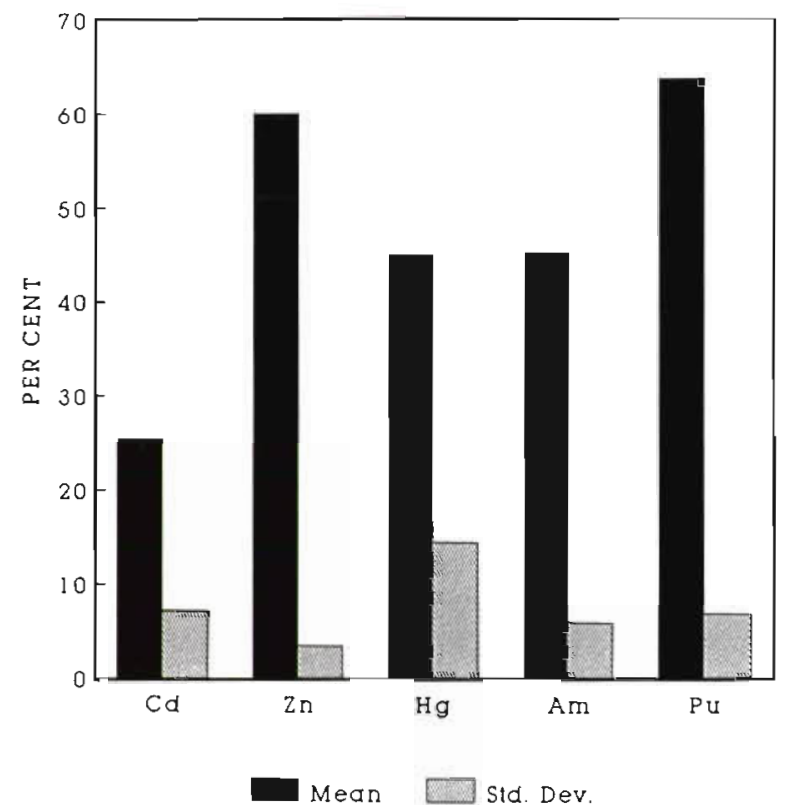

Fig. 1. Isochrysis galbana. Retention of ${ }^{109} \mathrm{Cd},{ }^{65} \mathrm{Zn},{ }^{203} \mathrm{Hg}$, ${ }^{241} \mathrm{Am}$, and ${ }^{237} \mathrm{Pu}$ in algal cells in copepod feeding suspensions after $18 \mathrm{~h}$ feeding. Values are mean percentages of the metal contents per cell at time 0 of feeding from 4 experimental flasks

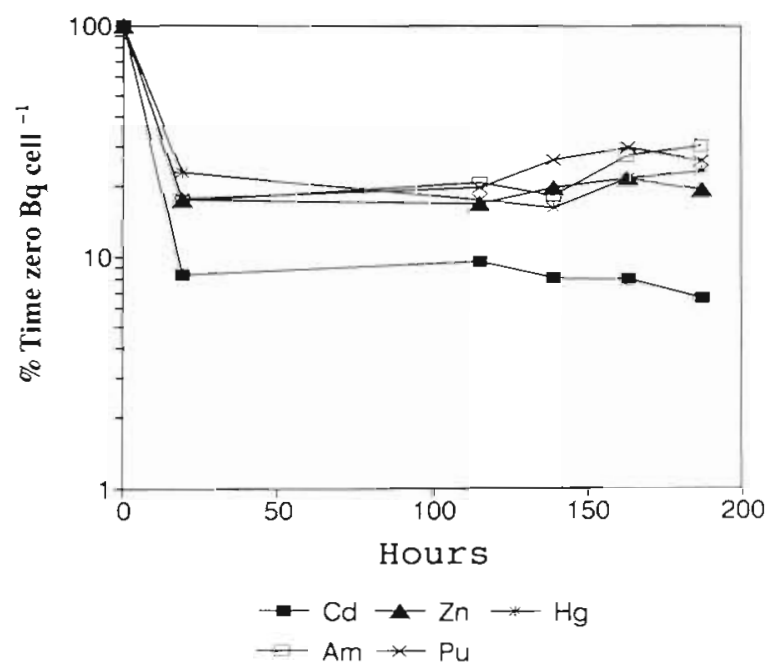

Fig. 2. Isochrysis galbana. Retention of ${ }^{109} \mathrm{Cd},{ }^{65} \mathrm{Zn},{ }^{203} \mathrm{Hg}$, ${ }^{241} \mathrm{Am}$, and ${ }^{237} \mathrm{Pu}$ in algal cells resuspended into unlabeled seawater in the absence of copepods. Values are percentages of metal radioactivity at time 0 of resuspension

cell density upon resuspension from radioactive water to unlabeled water (in the absence of copepods by 23 fold, from $140 \times 10^{4} \mathrm{ml}^{-1}$ to $6.1 \times 10^{4} \mathrm{ml}^{-1}$; with copepods by 12 -fold, to $11.4 \times 10^{4} \mathrm{ml}^{-1}$ ).

Fecal pellets produced during and after feeding on radiolabeled food contained essentially all the radioactivity excreted by the copepods. Loss of metals from these fecal pellets over time is depicted in Fig. $3,{ }^{109} \mathrm{Cd}$ and ${ }^{65} \mathrm{Zn}$ are not shown in Fig. 3 since levels were undetectable in fecal pellets after $18 \mathrm{~h}$ of depuration, and the released radioactivity was quantitatively recovered in the seawater. Most of the activity of the other radioisotopes $\left({ }^{203} \mathrm{Hg},{ }^{241} \mathrm{Am},{ }^{237} \mathrm{Pu}\right)$ was also released rapidly into the dissolved phase, although levels were still detectable in the fecal pellets. There were no significant differences between radioactivity of the peliets incubated at $2^{\circ} \mathrm{C}$ and $15^{\circ} \mathrm{C}$, suggesting that bacterial activity was either unimportant in release of the metals or that bacterial activity was comparable at the 2 temperatures. Only ${ }^{203} \mathrm{Hg}$ showed appreciable long-term retention in fecal pellets, with over $20 \%$ of initial ${ }^{203} \mathrm{Hg}$ content retained after 3 wk of depuration (Fig. 3). By contrast, $<1 \%$ of the ${ }^{241} \mathrm{Am}$ and ${ }^{237} \mathrm{Pu}$ in fecal pellets was retained after 3 wk depuration (Fig. 3). Invoking a 2-compartment loss curve to describe ${ }^{203} \mathrm{Hg}$ release from the fecal pellets, retention half time of the slowly exchanging pool of this isotope in the fecal pellets was ca $25 \mathrm{~d}$.

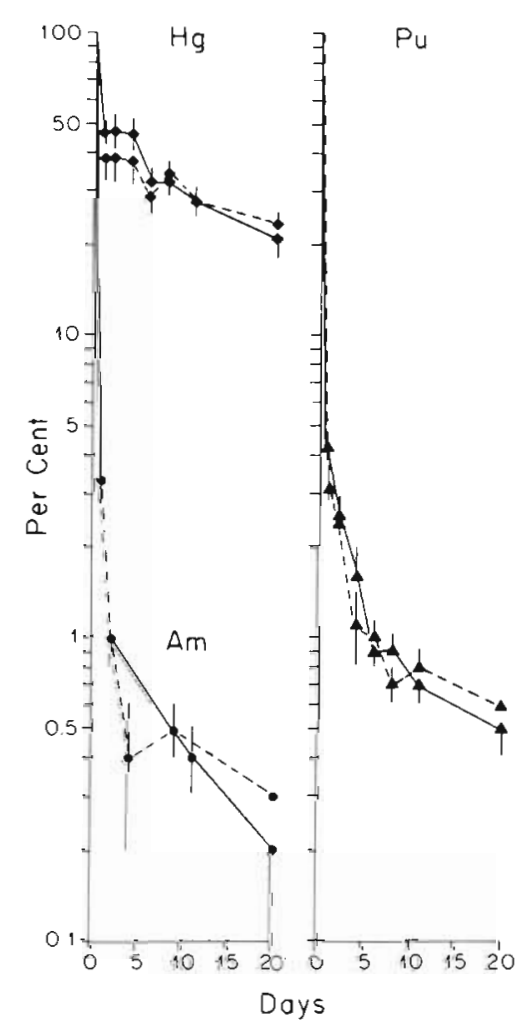

Fig. 3. Anomalocera patersoni. Retention of ${ }^{203} \mathrm{Hg},{ }^{241} \mathrm{Am}$, and ${ }^{237} \mathrm{Pu}$ in fecal pellets produced by copepods feeding on radioactive suspensions of Isochrysis galbana cells. ${ }^{109} \mathrm{Cd}$ and ${ }^{65} \mathrm{Zn}$ in pellets were below detection limits after $1 \mathrm{~d}$ of depuration. Dashed lines denote $2{ }^{\circ} \mathrm{C}$ incubations, continuous lines $15^{\circ} \mathrm{C}$ incubations. Error bars denote 1 o propagated counting errors 


\section{DISCUSSION}

The efficiency with which Anomalocera patersoni retained these metals was consistent with values obtained for other adult calanoid copepods: Acartia tonsa, Acartia hudsonica, and Temora longicornis fed uniformly labeled diatoms (Thalassiosira pseudonana), in which $\mathrm{Cd}$ had a retention efficiency of $30 \%, \mathrm{Zn}$ a retention efficiency of $47 \%$ (when copepods were fed algae in the same physiological state as the Isochrysis galbana in this study), and Am a retention efficiency of $0.9 \%$ (Reinfelder \& Fisher 1991). While Pu and Hg were not examined in the Reinfelder \& Fisher study, Ag, a Class B metal like Hg (Nieboer \& Richardson 1980) with very strong affinity for sulfur and protein, had a retention efficiency of $17 \%$, comparable to the $\mathrm{Hg}$ value in Anomalocera patersoni. In the euphausiid Meganyctiphanes norvegica, fed radiolabeled Artemia sp., inorganic $\mathrm{Hg}$ was assimilated into tissues with a $36 \%$ efficiency, while methyl $\mathrm{Hg}$ was assimilated with $97 \%$ efficiency (Fowler et al. 1976b). Euphausiids also assimilated ca $0 \%$ of ingested Pu (Fowler et al. 1976a) and Am (Fisher et al. 1983b), suggesting that the crustacean zooplankters in general cannot assimilate these nonessential actinides. Reinfelder \& Fisher (1991) also demonstrated a direct correlation between the retention efficiency of ingested elements (C, Se, P, Cd, Ag, Am, $\mathrm{Zn}, \mathrm{S}$ ) in copepods and the presence of the elements in the cytoplasm of the copepods' diatom food, suggesting that the copepods obtained all their nutrition from the cytosol. Elements associated with cell walls and plasmalemmae were defecated.

Given these retention efficiencies, it could be expected that the actinides would be rapidly defecated by copepods ingesting them in their food. Rapidly sinking fecal pellets would serve to depurate surface waters of these elements and possibly enrich deeper waters or sediments, depending on the sinking speeds of the pellets and their retention of these elements. Thus, these unassimilated elements would not enter into the organic cycle in the sea and would not be recycled much, if at all, in surface waters, leading to relatively short residence times in surface waters. By contrast, those elements which are assimilated in planktonic organisms and thereby enter the organic cycle are recycled appreciably in surface waters, and their oceanic residence times are much greater (Whitfield \& Turner 1987). The contrast in biogeochemical behavior between assimilated and unassimilated elements is perhaps most apparent in the fate of ${ }^{210} \mathrm{Po}$ and its radioactive grandparent ${ }^{210} \mathrm{~Pb}$. While both radionuclides are appreciably concentrated in phytoplankton (Fisher et al. 1983c, 1987), only ${ }^{210}$ Po enters into the cytoplasm of the cell (Fisher et al. 1983c), becomes assimilated in marine zooplankton (Cherry et al. 1983), and is recycled in surface waters (Tanaka et al. 1983). $\mathrm{Pb}$ largely remains bound to the surface of algal cells (Schultz-Baldes \& Lewin 1976, Fisher et al. 1983c), is not assimilated, being eliminated in fecal pellets (Fowler 1977), shows negligible recycling, and has a comparatively short residence time in surface waters (Bacon et al. 1976, Tanaka et al. 1983, Todd et al. 1986).

In general, we speculate that Class $A$ elements such as the lanthanides, the actinides, $\mathrm{Al}, \mathrm{Sn}$, and others which are particle-reactive and have a strong propensity for hydrolysis would show little penetration into algal cytoplasm and negligible retention in zooplankters. This would account for their relatively short residence times in the oceans (Broecker \& Peng 1982). The Class B and borderline metals (most of the transition metals), even those with no apparent biological function (e.g. Cd, Hg, $\mathrm{Ag}, \mathrm{Au}, \mathrm{Pt}$ ), would be expected to show some assimilation and therefore greater recycling in the mixed layer, accounting for their longer residence times (Broecker \& Peng 1982). Consistent with this idea, both $\mathrm{Cd}$ and $\mathrm{Hg}$ are found in the cytoplasm of Isochrysis galbana cells (Davies 1974, Li 1980) and would therefore be expected to assimilate in grazers, as shown in this report.

Retention of metals in zooplankton fecal pellets was surprisingly low, and contrasts with findings of other studies, especially for the transuranic elements where retention half times have been observed to range up to $50 \mathrm{~d}$ in zooplankton fecal pellets (Fowler et al. 1976a, Fisher et al. 1983b). This discrepancy may have been due to the use of different food types and zooplankton species in these studies. Of the 5 metals examined in the present study only $\mathrm{Hg}$ was appreciably retained by the fecal pellets after $1 \mathrm{~d}$ depuration. Reasons for the different behavior of $\mathrm{Hg}$ from that of the other metals are not clear, although it may be relevant that $\mathrm{Hg}$ has an unusually strong affinity for S (Sillén \& Martell 1964) and may be bound to excreted protein contained within fecal pellets. Both inorganic and methyl mercury were retained to an even greater extent in euphausiid fecal pellets than in copepod pellets in the present study (Fowler et al. 1976b). Consistent with these observations, Gill \& Fitzgerald (1988) estimated a rather short oceanic residence time for $\mathrm{Hg}$ of about $350 \mathrm{yr}$, suggesting that biogenic debris could effectively transport $\mathrm{Hg}$ to deep waters. Gill \& Fitzgerald (1988) also noted that $\mathrm{Hg}$ has comparable vertical profiles and oceanic residence times to those of other particle-reactive metals (including $\mathrm{Pu}$ and $\mathrm{Pb}$ ) which also enter ocean surface waters primarily via atmospheric deposition.

Given that the released metals were found in the dissolved phase (i.e. $<0.2 \mu \mathrm{m}$ ) in the water overlying the fecal pellets, and given that $\mathrm{Hg}$ was still recovered in the fecal pellets, it is possible to rule out the argument that small pieces of fecal material simply broke off and accounted for the observed loss. Instead, the results are 
consistent with the idea that the metals ( $\mathrm{Hg}$ excepted) were contained in a dissolved state and were initially deposited by the copepods within the fecal pellets (hence the high level of radioactivity detected in the pellets when they were first produced), but diffused out of the pellets over time; this hypothesis and the extent to which it is diet-dependent remain untested, however. This fecal-pellet 'pore water' containing metals has not been apparent in other studies of metal retention by fecal pellets of euphausiids (Fisher et al. 1983b) or small calanoid copepods, even when feeding on the same Isochrysis galbana diet (Fisher \& Reinfelder 1991, Fisher \& Lee unpubl.). In any case, the present results indicate that fecal pellets produced by the pontellid copepod Anomalocera patersoni would not be effective in vertically transporting to the deep ocean metals which had been ingested and defecated by these organisms, although they could help depurate surface waters of these metals. Fecal pellets of other crustacean zooplankters, by comparison, can be shown to be effective in transporting particle-reactive metals to the deep ocean (Fowler \& Knauer 1986, Fisher \& Fowler 1987). Furthermore, these (and other) fecal pellets may be effective as scavenging agents of dissolved or colloidal metal from ambient water during their descent in the water column (Fowler et al. 1983, Fisher et al. in press).

The release of radionuclides from Isochrysis galbana cells generally followed a 2-compartment loss curve, comparable to observations for other algal species (Fisher et al. 1983a). The low retention of Cd by the algae (and fecal pellets) probably reflects this metal's strong affinity for chloride in seawater (Turner et al. 1981), which results in reduced particle affinity in seawater (Braek et al. 1980). The greater binding of the other metals to these cells is consistent with observations made for other species of phytoplankton, including diatoms, coccolithophores, and chlorophytes (Fisher et al. 1983a, 1984). Modest differences were observed between the 2 actinides, ${ }^{237} \mathrm{Pu}$ and ${ }^{241} \mathrm{Am}$. ${ }^{237} \mathrm{Pu}$ was more strongly bound to these algal cells, had a slightly lower retention efficiency in copepods, and was lost more slowly from egested fecal pellets.

Acknowledgements. We thank J.-L. Teyssié for technical assistance and anonymous reviewers for helpful comments. The research was supported by NSF OCE 8810657 and by the International Atomic Energy Agency. The I.A.E.A. International Laboratory of Marine Radioactivity operates under a bipartite agreement between the I.A.E.A. and the Government of the Principality of Monaco.

\section{LITERATURE CITED}

Bacon, M. P., Spencer, D. W., Brewer, P. G. (1976). ${ }^{210} \mathrm{~Pb} /{ }^{226} \mathrm{Ra}$ and ${ }^{210} \mathrm{Po} /{ }^{210} \mathrm{~Pb}$ disequilibria in seawater and suspended particulate matter. Earth planet. Sci. Lett. 32: 277-296
Braek, G. S., Malnes, D., Jensen, A. (1980). Heavy metal tolerance of marine phytoplankton. IV. Combined effects of zinc and cadmium on growth and uptake in some marine diatoms. J. exp. mar. Biol. Ecol. 42: 39-54

Broecker, W. S., Peng, T.-H. (1982). Tracers in the sea. Eldigio Press, New York

Bruland, K. W., Coale, K. (1986). Surface water ${ }^{234} \mathrm{Th} /{ }^{238} \mathrm{U}$ disequilibria: spatial and temporal variations of scavenging rates within the Pacific Ocean. In: Burton, J. D., Brewer, P. G., Chesselet, R. (eds.) Dynamic processes in the chemistry of the upper ocean. Plenum Press, New York, p. 159-172

Cherry, R. D., Heyraud, M., Higgo, J. J. W. (1983). Polonium210: its relative enrichment in the hepatopancreas of marine invertebrates. Mar. Ecol. Prog. Ser. 13: 229-236

Cherry, R. D., Higgo, J. J. W., Fowler, S. W. (1978). Zooplankton fecal pellets and element residence times in the ocean. Nature, Lond. 274: 246-248

Clegg, S. L., Sarmiento, J. L. (1989). The hydrolytic scavenging of metal ions by marine particulate matter. Prog. Oceanogr. 23: 1-21.

Davies, A. G. (1974). The growth kinetics of Isochrysis galbana in cultures containing sublethal concentrations of mercuric chloride. J. mar. biol. Ass. U.K. 54: 157-169

Fisher, N. S. (1986). On the reactivity of metals for marine phytoplankton. Limnol. Oceanogr. 31: 443-449

Fisher, N. S., Bjerregaard, P., Fowler, S. W. (1983a). Interactions of marine plankton with transuranic elements. 1. Biokinetics of neptunium, plutonium, americium, and californium in phytoplankton. Limnol. Oceanogr. 28: $432-447$

Fisher, N. S., Bjerregaard, P., Fowler, S. W. (1983b). Interactions of marine plankton with transuranic elements. 3. Biokinetics of americium in euphausiids. Mar. Biol. 75: 261-268

Fisher, N. S., Bohé, M., Teyssié, J.-L. (1984). Accumulation and toxicity of $\mathrm{Cd}, \mathrm{Zn}, \mathrm{Ag}$, and $\mathrm{Hg}$ in four marine phytoplankters. Mar. Ecol. Prog. Ser. 18; 201-213

Fisher, N. S., Burns, K. A., Cherry, R. D., Heyraud, M. (1983c). Accumulation and cellular distribution of ${ }^{241} \mathrm{Am},{ }^{210} \mathrm{Po}$, and ${ }^{210} \mathrm{~Pb}$ in two marine algae. Mar. Ecol. Prog. Ser. 11: 233-237

Fisher, N. S., Cochran, J. K., Krishnaswami, S., Livingston, H. D. (1988). Predicting the oceanic flux of radionuclides on sinking biogenic debris. Nature, Lond. 225: 622-625

Fisher, N. S., Fowler, S. W. (1987). The role of biogenic debris in the vertical transport of transuranic wastes in the sea. In: O'Connor, T. P, Burt, W. V., Duedall, $l$. W. (eds.) Oceanic processes in marine pollution, Vol. 2. Krieger, Malibar, p. $197-207$

Fisher, N. S., Nolan, C. V., Fowler, S. W. (in press). Scavenging and retention of metals by zooplankton fecal pellets and marine snow. Deep Sea Res.

Fisher, N. S., Reinfelder, J. R. (1991). Assimilation of selenium in the marine copepod Acartia tonsa studied with a radiotracer ratio method. Mar. Ecol. Prog. Ser. 70: 157-164

Fisher, N. S., Teyssié, J.-L., Krishnaswami, S., Baskaran, M. (1987). Accumulation of $\mathrm{Th}, \mathrm{Pb}, \mathrm{U}$, and $\mathrm{Ra}$ in marine phytoplankton and its geochemical significance. Limnol. Oceanogr. 32: 131-142

Fowler, S. W. (1977). Trace elements in zooplankton particulate products. Nature, Lond. 269: 51-53

Fowler, S. W (1982). Biological transfer and transport processes. In: Kullenberg. G. (ed.) Pollutant transfer and transport in the sea, Vol 2. CRC Press, Boca Raton, Florida, p. $1-65$

Fowler, S. W., Ballestra, S., La Rosa, J., Fukai, R. (1983). 
Vertical transport of particulate-associated plutonium and americium in the northeast Pacific. Deep Sea Res. 30: $1221-1233$

Fowler, S. W., Heyraud, M., Cherry, R. D. (1976a). Experimental studies on plutonium kinetics in marine biota. In: Activities of the International Laboratory of Marine Radioactivity, 1976 Report. International Atomic Energy Agency, Vienna, p. 42-50

Fowler, S. W., Heyraud, M., LaRosa, J. (1976b). Mercury kinetics in marine zooplankton. In: Activities of the International Laboratory of Marine Radioactivity, 1976 Report. International Atomic Energy Agency, Vienna, p. 20-33

Fowler, S.W., Knauer, G. A. (1986). Role of large particles in the transport of elements and organic compounds through the oceanic water column. Prog. Oceanogr. 16: 147-194

Gill, G. A., Fitzgerald, W. F. (1988). Vertical mercury distributions in the aceans. Geochim. cosmochim. Acta 52: $1719-1728$

Guillard, R. R. L., Ryther, J. H. (1962). Studies of marine planktonic diatoms I. Cyclotella nana Hustedt, and Detonula confervacea (Cleve) Gran. Can. J. Microbiol. 8: 229-239

Kiørboe, T., Møhlenberg, F., Hamburger, K. (1985). Bioenergetics of the planktonic copepod Acartia tonsa: relation between feeding, egg production and respiration, and composition of specific dynamic action. Mar. Ecol. Prog. Ser. 26: 85-97

Li, W. K. W (1980). Cellular accumulation and distribution of cadmium in Isochrysis galbana during growth inhibition and recovery. J. Plankton Res. 2: 283-294

Lovett, M. B., Nelson, D. M. (1981). Determination of some oxidation states of plutonium in seawater and associated particulate matter. In: Techniques for identifying transuranic speciation in aquatic environments. International Atomic Energy Agency, Vienna, p. 27-35

Lowman, F. G., Rice, T. R., Richards, F. R. (1971). Accumulation and redistribution of radionuclides by marine organisms. In: Radioactivity in the marine environment. National Academy of Sciences, Washington, D.C., p. 161-199

Moore, W. S., Dymond, J. (1988). Correlation of ${ }^{210} \mathrm{~Pb}$ removal with organic fluxes in the Pacific Ocean. Nature, Lond. 331: $339-341$

This article was submitted to the editor
Murray, J. W., Downs, J. N., Strom, S., Wei, C.-L., Jannasch, H. W. (1989). Nutrient assimilation, export production and ${ }^{234} \mathrm{Th}$ scavenging in the eastern equatorial Pacific. Deep Sea Res. 36: 1471-1489

Nieboer, E., Richardson, D. H. (1980). The replacement of the nondescript term 'heavy metals' by a biological and chemically significant classification of metal ions. Envir Pollut. (Ser. B) 1: 3-26

Pechenik, J. A., Fisher, N. S. (1979). Feeding, assimllation, and growth of mud snail larvae, Nassarius obsoletus (Say), on three different algal diets. J. exp. mar. Biol. Ecol. 38: 57-80

Reinfelder, J. R, Fisher, N. S. (1991). The assimilation of elements ingested by marine copepods Science 251: 794-796

Santschi, P. H. (1984). Particle flux and trace metal residence time in natural waters. Limnol. Oceanogr. 29: 1100-1108

Schultz-Baldes, M., Lewin, R. A. (1976). Lead uptake in two marine phytoplankton organisms. Biol. Bull. mar biol. Lab., Woods Hole 150: 118-127

Sillén, L. G., Martell, A. E. (1964). Stability constants of metalion complexes. The Chemical Society Spec. Publ. No. 17, London

Tanaka, N., Takeda, Y., Tsunogai, S. (1983). Biological effect on removal of Th-234, $\mathrm{Po}-210$ and $\mathrm{Pb}-210$ from surface water in Funka Bay, Japan. Geochim. cosmochim. Acta 47 : $1783-1790$

Todd, J. F., Wong, G. T F., Reid, D. F. (1986). The geochemistries of ${ }^{210} \mathrm{Po}$ and ${ }^{210} \mathrm{~Pb}$ in waters overlying and within the Orca Basin, Gulf of Mexico. Deep Sea Res. 33: 1293-1306

Turner, D. R., Whitfield, M., Dickson, A. G. (1981). The equilibrium speciation of dissolved components in freshwater and seawater at $25^{\circ} \mathrm{C}$ and $1 \mathrm{~atm}$ pressure. Geochim. cosmochim. Acta 45: 855-881

Wangersky, P. (1986). Biological control of trace metal residence time and speciation: a review and synthesis. Mar. Chem. 18: 269-297

Whitfield, M., Turner, D. R. (1987). The role of particles in regulating the composition of seawater. In: Stumm, W. (ed.) Aquatic surface chemistry: chemical processes at the particle-water interface. Wiley, New York, p. 457-493

Manuscript first received: September 6, 1990 Revised version accepted: December 21, 1990 